\title{
PROSPECTS FOR BIODIESEL AS A BYPRODUCT OF WOOD PULPING - A REVIEW
}

Sa Yong Lee, ${ }^{a}$ Martin A. Hubbe, ${ }^{\mathrm{a}^{*}}$ and Shiro Saka ${ }^{\mathrm{b}}$

\begin{abstract}
Effective utilization of byproducts can affect the profitability of kraft pulping to produce cellulosic fibers from wood. This review considers opportunities to use tall oil components, obtained from kraft pulping, as a source of raw material for biodiesel fuel, or as a source of additives for petrodiesel. Considerable progress has been achieved with respect to converting vegetable oils to diesel fuel, and some of what has been learned appears to have potential application for processing of wood-derived fatty acids and related compounds. Alkaline-catalyzed transesterification strategies, while seemingly well adapted for relatively pure vegetable oil source materials, may not be the best fit for the processing of tall oil fractions. The promising strategies to consider include acid-catalyzed esterification, enzymatic processes, hydrogenation, and the use of supercritical methanol.
\end{abstract}

Keywords: Biodiesel, Diesel fuels, Tall oil, Kraft pulping, Transesterification, Esterification, Catalysis, Biorefinery, Extractives

Contact information: a: Department of Forest Biomaterials Science and Engineering, North Carolina State University, Box 8005, Raleigh, NC 27695-8005 USA; b: Department of Socio-Environmental Energy Science, Graduate School of Energy Science, Kyoto University, Yoshida-honmachi, Sakyo-ku 606-8501, Japan; *Corresponding author: hubbe@ncsu.edu

\section{INTRODUCTION}

\section{Why Biodiesel from Wood?}

Though biodiesel products are most often associated with chemical conversion of vegetable oils and seed oils, there is a powerful incentive to use lignocellulosic materials as an additional source for chemicals and fuels production. Because lignocellulosic materials constitute by far the largest proportion of biomass (Berndes et al. 2003; Kavalov and Peteves 2005; McKay 2006), such materials can be expected to help our society deal with the increasing scarcity of easily extractable petroleum (Berndes et al. 2003; Tester et al. 2005). The relatively low content of triglyceride oils and fatty acids in wood, e.g., about 1$3 \%$ (Back and Allen 2000), must be viewed in the context of the huge volume of wood that is efficiently processed each year into pulp to be used in the manufacture of paper, e.g., about 330 million tons worldwide (DeKing 2004). Though about half of the fiber needed for paper production comes from recycling, most of the remainder comes from the pulping of wood. In other words, the huge volumes of throughput can justify further work to maximize the value of various byproducts.

The pulping industry already has evolved a reasonably efficient "biorefinery" process, yielding cellulose in relatively pure form, while incinerating the lignin portion of 
the wood to produce energy and recover most of the chemicals that were used to dissolve the lignin (Smook 1992). The burning of the lignin can supply a large proportion of the energy needed to run an integrated pulp and paper facility. In fact, technology is under development that holds promise to make such facilities net producers of electrical energy (Axegard et al. 2002).

Further potential for improving overall profitability often can be found in cases where certain chemical byproducts of pulping have a higher market value, compared to the value of the heat that can be recovered from them by incineration of pulping liquors. A conventional kraft pulp mill produces a byproduct called tall oil, which is a mixture of triglyceride oils, fatty acids, resin acids, other terpenoids, and other related materials (Johansson 1982). Though it is possible to incinerate these materials to recover their energy content, the market provides incentives to use or convert these materials for highermargin applications. Diesel fuel is one such potential application. Though a cynic may point out that one is merely changing the location at which material is being incinerated, in a diesel engine rather than in a recovery boiler, diesel engines require fuel that has much higher purity, as well as more stringently specified properties. For instance, diesel fuel in the US must meet ASTM standards for acid number (test D 664), additive elements in lubricating oils (D 4951), total sulfur (D 5453), sulfate ash (D 874), and water and sediment (D 2709) (Ven Gerpen et al. 2004a). The market price of diesel fuel can be many times greater than the heat value of tall oil. During the period between January 2004 and June 2006 , the price of diesel fuel approximately doubled from $\$ 1.57$ to about $\$ 2.90$ per gallon (DOE 2006a). To put this in context, the price of crude tall oil historically has been in the range of $\$ 90$ to $\$ 160$ per ton (Innov. Group 2006), a number which suggests a price per gallon of tall oil less than $\$ 1$.

Petroleum-based diesel oil (PD) is an important automotive fuel (Song et al. 2000), with particular dominance in the heavy truck fuel market. As an auto fuel, diesel is popular in Europe, where high taxes have provided additional incentives to maximize fuel efficiency. Recent analysis indicates that the world supply of easily-extracted petroleum will soon reach and pass its "peak" if, in fact, it has not done so already (Hirsh et al. 2006). In light of the expected tightening of demand, one can expect that greater demand for energy-efficient vehicle technologies will pervade all regions of the world.

Combustion of petroleum-derived diesel fuel yields a net increase of carbon dioxide, which is considered to contribute to global warming (Drake 2000; OECD/IEA 2000; Tester et al. 2005). In addition, combustion of petroleum products often contributes to sulfuric pollution, a significant contribution to acid rain. Though there are those who doubt the certainty of the environmental effects (Lomborg 2001; Labohm et al. 2004), the weight of evidence appears to favor urgent action to limit net production of $\mathrm{CO}_{2}$ and other greenhouses gases.

Accelerated by the oil crisis of the $1970 \mathrm{~s}$, there has been increasing research in alternative fuels (Hunt 1983; Lee 1996; da Rosa 2005; Tester et al. 2005). Research has focused on methanol, ethanol, compressed natural gas (CNG), liquid petroleum gas (LPG), liquefied natural gas (LNG), vegetable oils, reformulated gasoline, and reformulated diesel oil (Canakci and van Gerpen 2001a). Biomass fuels (Wyman and Goodman 1993; Vasudevan et al. 2005) offer particular promise, since the starting material can be highly 
abundant, and it is obtained by photosynthesis, minimizing the net production of $\mathrm{CO}_{2}$ during the fuel product lifecycle (Sheehan et al. 1998).

From the standpoint of conventional biodiesel production, the composition of tall oil is far from ideal. As will be reviewed in the next section, the most widely used procedures for biodiesel production begin with the conversion of triglyceride oils to the corresponding methyl esters, plus glycerol (Schuchardt et al. 1998). Although triglycerides can comprise a substantial proportion of the extractives component of wood (Back and Allen 2000), essentially all of that material becomes saponified under the hot, highly alkaline conditions of a kraft cook. The alkaline conditions most often employed during production of biodiesel products from vegetable oils would tend to leave the fatty acids in their soap form, and the physical behavior of soap tends to interfere with the desired conversion to biodiesel. Before considering these issues further, it can be instructive to review progress that has been achieved with respect to biodiesel production from highgrade vegetable oils.

\section{Lessons to be Learned from Existing Biodiesel Technology}

To set the stage for consideration of tall oil as a biodiesel source, it makes sense to review various lessons that can be learned from present-day biodiesel technology, most of which is based on the use of vegetable oils. In the present discussion biodiesel will be defined as a composition in which fatty acids have been converted to alkyl esters (usually methyl esters). Unrefined vegetable oil itself is sometimes called "biodiesel," despite the fact that direct substitution of such oil in conventional diesel engines can cause problems in unmodified vehicles (Goering et al. 1982; Bagby 1987).

The relatively high viscosity and low volatility of vegetable oils can lead to enginerelated deposits, injector coking, and piston ring sticking (Clark et al. 1984; Pestes and Stanislao 1984; Vellguth 1988). Such effects usually can be reduced or eliminated by converting vegetable triglyceride oils to their corresponding lower-viscosity methyl esters through a process of transesterification (Kusdiana and Saka 2001a, 2001b, 2004a, 2004b, 2004c; Saka and Kusdiana 2001a, 2001b; Shimada et al. 2002; Van Gerpen et al. 2004a; Warabi et al. 2004a, 2004b; Wang et al. 2005; Demirbas 2005; Imahara et al. 2006; Minami and Saka 2006). The resulting product is often called biodiesel. Transesterification of high-grade vegetable oil can produce a fuel having viscosity and many other characteristics that are similar to those of No. 2 diesel fuel. The transesterification can reduce viscosities from an initial $27-54 \mathrm{~mm}^{2} / \mathrm{s}$ down to about $4-5 \mathrm{~mm}^{2} / \mathrm{s}$ (Demirbas 2005). Another approach is to hydrolyze the triglycerides in sub-critical water to obtain fatty acids, and, in a second step, to esterify the freshly prepared fatty acids with supercritical methanol, together with the originally existing free fatty acids (Kusdiana and Saka 2004a, 2004c; Minami and Saka 2006).

Mittelbach (1996) describes the development of specifications for biodiesel composition and properties. Austria was the first to establish standards, which were in place by 1992, followed by others, including a German standard (DIN V 51606) in 1994. Strict limits are specified for density, viscosity, flash point, sulfur, carbon residue, sulfate ash, cetane number (a higher number indicating a shorter delay of auto-ignition under compression in a diesel engine), and neutralization number (related to the titratable acid 
group content). Biodiesel derived from vegetable oils also needs to fall below prescribed maximum levels for methanol, free and total glycerol, as well as phosphorous. In the US, ASTM test number D 6751-02 describes the requirements for a product to qualify as biodiesel in the US (Van Gerpen et al. 2004b).

When the source material is a relatively pure mixture of triglycerides, transesterification can be carried out as illustrated by the reaction scheme in Fig. 1. The reaction is promoted by alkaline conditions and by the presence of solid catalysts, such as zeolites (Suppes et al. 2003), calcium compounds (Gryglewicz 1999), benzenesulfonic acid (Dittmar et al. 2003), as well as by lipase (Abigor et al. 2000; Arsan and Parken 2000). Glycerol, which is formed as a byproduct of the reaction, has applications in a worldwide production of 0.7-0.8 million ton for pharmaceutical, cosmetics, food, and plastics.

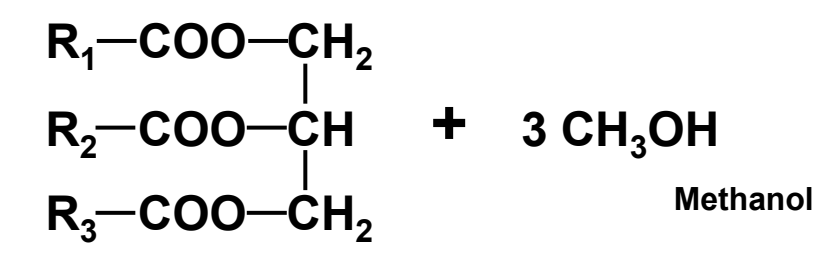

Triglycerides
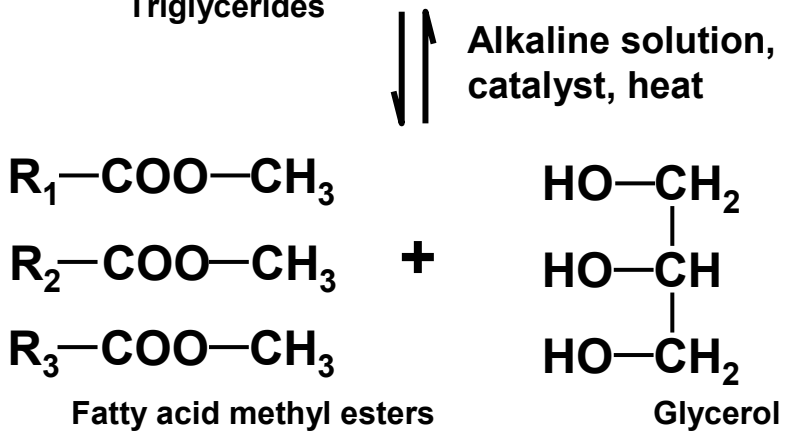

Fig. 1. Transesterification reaction suitable for relatively pure vegetable oils.

According to Fig. 1, the quality of biodiesel fuel prepared from relatively pure vegetable oils is often considered to be superior, in some respects, to that of conventional petrodiesel (Van Gerpen et al. 2004a). High-quality biodiesel can be added to petrodiesel to reduce the resulting emissions. Biodiesel produced from triglycerides is biodegradable and nontoxic. The exhaust emissions tend to be cleaner. No engine modification is needed. In addition, the Occupational Safety and Health Administration (OSHA) in the US considers biodiesel to be nonflammable, due to its high flash point of $160{ }^{\circ} \mathrm{C}$. It follows that biodiesel is safer to store and use, compared to its petroleum counterpart, which has a flash point of $>62{ }^{\circ} \mathrm{C}$. For sake of comparison, gasoline is even more flammable, having a flash point of $>45^{\circ} \mathrm{C}$.

Figure 2 shows a typical process for the continuous production of biodiesel, using homogeneous catalysis (Bournay et al. 2005). Especially in the case of waste vegetable oil, when using alkali catalyst, the first step involves removal of water. Strong alkali is added as a catalyst to the methanol solution in a closed reaction vessel, vegetable oil is added, and 
the vessel is then sealed to prevent loss of alcohol. The temperature is raised to about 55$70{ }^{\circ} \mathrm{C}$ to promote the reaction that was shown in Fig. 1. Competing reactions can be minimized usually by adding an excess of the alcohol, beyond the stoichiometric amount needed to react with the triglycerides (Bournay et al. 2005). The usual reaction time varies between one to eight hours, partly dependent on the temperature. Based on the Arrhenius equation, the reaction rate is expected to double with each increase of $10{ }^{\circ} \mathrm{C}$. As shown, glycerol is separated from the mixture after the transesterification stage. The higher density of glycerol allows gravity separation, though some operations include centrifugation to speed up the process. Residual alcohol in the glycerol phase is removed by distillation and reused. The separated oil phase is washed with water to remove any of the undesired soap that may have formed. Advances in the separation of glycerol and alkyl ester phases have been patented by Noureddini $(2000,2001)$. Fatty acids become a byproduct of the continuous alkali-catalyzed process, rather than being converted to biodiesel.

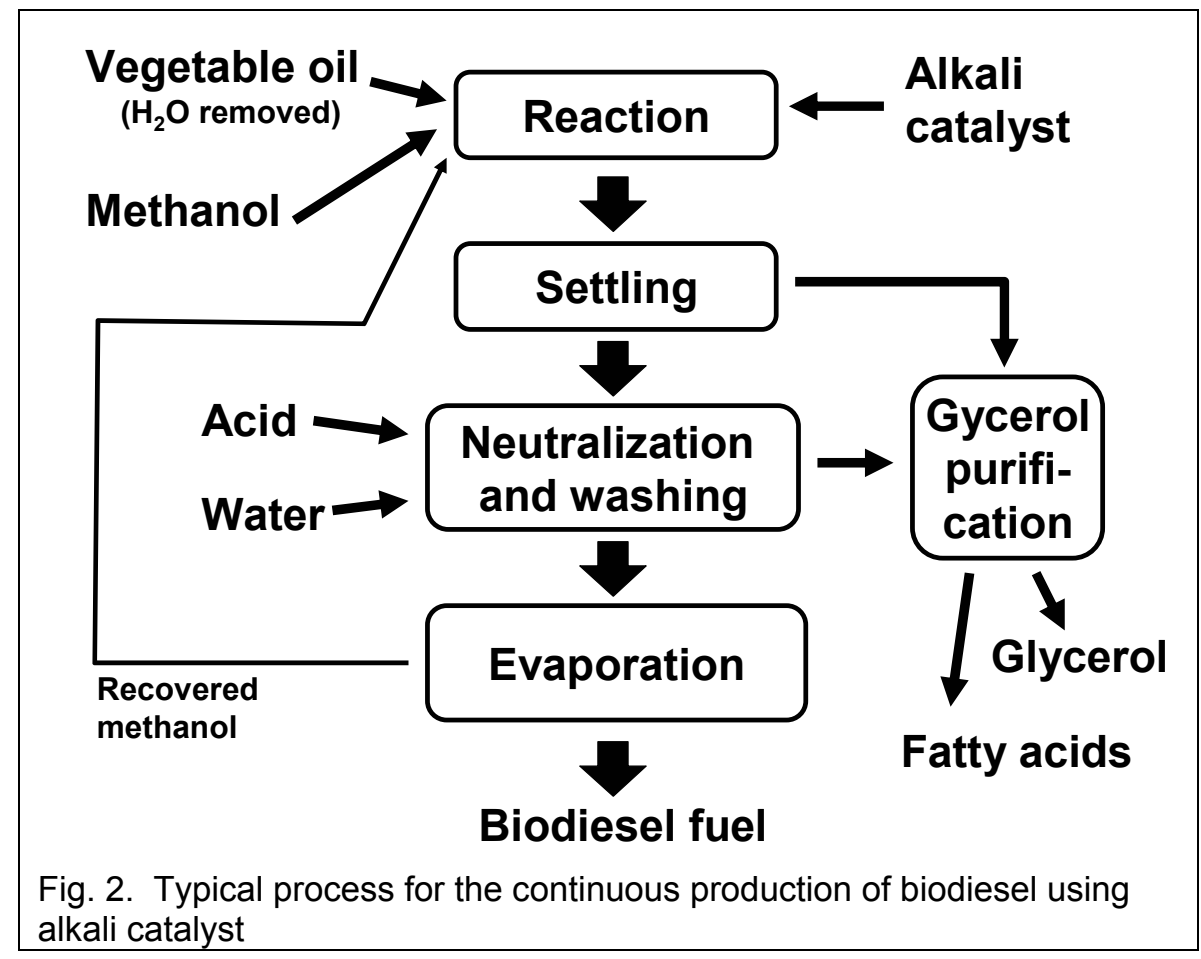

Work by Bookcock and coworkers showed that the rate of the initial reaction shown in Fig. 2 for alkali-catalyzed methylation can be increased considerably by use of a cosolvent, such as tetrahydrofuran (Bookcock et al. 1996a, 1998). The explanation is that the methanol and oil tend to exist as separate phases, thus limiting their ability to react with each other (Boocock et al. 1996b). The cosolvent allows the mixture to form a single phase. The molecular mechanism of alkali-catalyzed methylation, with an alumina catalyst, has been further elucidated by Vonghia et al. (1995). 


\section{Low-Temperature Performance and Blends}

Efforts to use tall oil as a source of diesel fuels need to take it into consideration some practical issues that are already experienced by users of biodiesel derived from vegetable oils. These issues include crystallization of saturated fatty acid alkyl esters in very cold weather and a higher likelihood of difficulty in getting a diesel motor to start (Dunn 1999; Tyson and McCormick 2006). In very cold weather, biodiesel may crystallize at higher temperatures than petrodiesel. The most common approach to avoid plugging of fuel filters and fuel lines in cold weather involves blending the biodiesel with petrodiesel. Various blends of biodiesel with substantial amounts of no. 2 low-sulfur diesel fuel and no. 1 kerosene have been used, depending on local costs of materials, seasonal temperatures, and engine characteristics (Dunn 1999; Tyson and McCormick 2006). Blends having ratios of $20 \%$ or less petrodiesel to biodiesel have become available in various locations (Sheehan et al. 1998). Though the results are highly dependent on the types of vegetable oils used to produce biodiesel, it has been found that the cloud point (an indication of crystallization) and the pour point of biodiesel-petrodiesel blends decreases almost linearly with the content of petrodiesel (DOE 2006b). Filter-plugging tests likewise showed substantial improvements in cold-weather performance, upon addition of petrodiesel to biodiesel, except that even B20 (20\% biodiesel) blends made from yellow grease or tallow oils continued to plug filters at temperatures as high as $0{ }^{\circ} \mathrm{C}$. For temperatures higher than room temperature it has been clearly shown that addition of petrodiesel to biodiesel tends to reduce the viscosity in a predictable way, making the fuel more suitable for use as a direct substitute for petrodiesel (Yuan et al. 2005). In addition to blends, there has been some success in preparing isopropyl and other branched-chain esters, which are reported to reduce the crystallization temperature (Johnson and Hammond 1996; Wang et al. 2005).

Further practical difficulties that can be encountered with biodiesel products are associated with its relatively high level of unsaturated hydrocarbon chains, as compared to petrodiesel (Peterson et al. 1996). As noted in later discussion, the lower content of unsaturated fatty acids in tall oil (Zachary et al. 1965) can be considered to be an advantage in this respect. Heating of unsaturated hydrocarbons is expected to cause polymerization, resulting in the formation of gums. Though more study is needed to clarify this issue, it would make sense that differences in gumming effect ought to be found when comparing biodiesel fuels derived from oils having differing content of highly unsaturated fatty acid chains. To ensure the highest quality of biodiesel, it has been recommended to minimize the level of linolenic acid and other highly unsaturated components (Mittelbach 1966; Lang et al. 2001). As noted by Knothe (2004), although a high degree of unsaturation can help suppress crystallization of biodiesel at cold temperatures, the conjugated double bonds are susceptible to oxidation during storage, forming species that do not perform well in diesel engines.

Water in biodiesel can create additional problems. Condensation during storage can increase the amount of water, compared to freshly made biodiesel. Water not only reduces the heat of combustion, but it can cause higher emissions levels, harder starting, slower acceleration, and corrosion of vital fuel system components. If the temperature falls below $0{ }^{\circ} \mathrm{C}$, ice crystals can plug lines or nucleate crystallization within the organic phase. Water also tends to accelerate microbial growth, since biodiesel can be considered an excellent 
food source for bacteria. Users of biofuels who employ heated tanks, for year-round use, can expect to face year-round problems with microbes (Van Gerpen et al. 2004b).

\section{BIODIESEL FROM HIGH FATTY ACID RAW MATERIALS}

Tall oil consists of a mixture of triglycerides, free fatty acids, resin acids, and a variety of other materials (Johansson 1982; Back and Allen 2000). Because the extractives component of wood typically contains high levels of fatty acids, as well as substantial amounts of water, it can be instructive to consider various progresses that have been achieved with other source materials having similar characteristics. Waste frying oil can serve as an example.

\section{Waste Vegetable Oil}

Waste vegetable oil comes mainly from industrial deep fryers in potato processing plans, snack food factories, and fast-food restaurants. Use of waste frying oils as a fuel source has been prompted by a desire to minimize costs, and also in order to avoid wasteful disposal of a resource (Zhang et al. 2003a, 2003b; Zaher et al. 2002; Felizardo et al. 2006; Kulkarni and Dalai 2006; Zheng et al. 2006). While the cost of waste frying oils is about half that of virgin vegetable oil (Supple et al. 2002), it is often possible to obtain relatively small amounts for free, picking it up from local fast-food restaurants. Such use reduces the burden of disposing of the oil as waste, maintaining public sewers, and treating oil-polluted water (Encinar et al. 2005). The amount of waste cooking oil produced has been estimated as up to one million tons per year in the EU countries (Supple et al. 2002), and about 120,000 tons per year, in the form of yellow grease, in Canada (Zhang et al. 2003a). According to a study done in 1993, the amount of yellow grease produced in the U.S. was approximately 1.5 billion pounds (0.7 million metric tons) (Hunter and Applewhite 1993). USDA yellow grease production estimates for the U.S. from 1995 to 2000 average 2.6 billion pounds (1.2 million metric tons), equivalent to 350 million gallons of biodiesel (Groschen 2002). In these studies yellow grease is defined as spent cooking oil and other fats and oils collected from commercial or industrial cooking operations.

From the standpoint of producing biodiesel, two of the biggest challenges in using waste frying oils are their water content and their free fatty acid content. Transesterification, as illustrated in Fig. 1, can carried out efficiently only in the case of sufficiently low levels of both water and free fatty acids in the feedstock (Ma et al. 1998; Saka 2004c). Transesterification can be defined as the conversion of one type of ester to another type of ester - in the present instance, from a triglyceride fat to a methyl or ethyl ester. Otherwise, the alkaline conditions used in this type of reaction cause saponification, converting an excessive amount of free fatty acids to their corresponding soap form, as illustrated in Fig. 3. The resulting soap tends to interfere with separation of the glycerol that is formed in the transesterification reaction.

The high temperatures of typical cooking processes and the water from the foods accelerate the hydrolysis of triglycerides and increase the free fatty acid content in the oil. Waste oil can have about 2 to $20 \%$ fatty acid content. Waste oil also has problems related to storage stability, partly due to polymerization of the unsaturated alkyl chains. Various 
chemical differences can be distinguished when comparing typical waste vegetable oils $v s$. virgin oils (Tomasevic and Siler-Marinkovic 2003).

\section{$\mathrm{R}-\mathrm{COOH}$}

Fatty acid

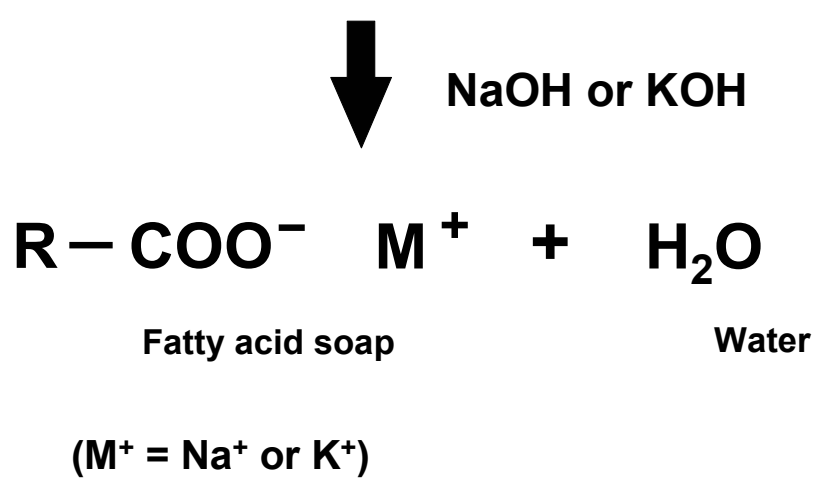

Fig. 3. Saponification reaction of fatty acids with alkali catalyst

Another critical point shown in Fig. 3 is the fact that the saponification of free fatty acids yields water. Water in the reaction mixture tends to hydrolyze triglycerides, lowering the yield and increasing the acid value. In the absence of water, hydrolysis of triglyceride esters cannot take place.

\section{Enzymatic Catalysis}

Enzymes offer a promising route to biodiesel in the case of source materials having high content of free fatty acid. For example, immobilized Candida Antarctica lipase has been used for ethyl esterification of docosahexanoic acid (Shimada et al. 2001). This method later was adopted to produce fatty acid methyl ester. Through multi-stage transesterification of triglycerides (Fig. 1) and the esterification of the fatty acids, more than $98.5 \%$ by mass of fatty acid methyl ester was obtained. The latter reaction is illustrated in Fig. 4 (Hsu et al. 2002; Watanabe et al. 2005). The high conversion was achieved by a 24-hour reaction, involving six stages of transferring the enzyme to a fresh substrate mixture.

In comparison to the other transesterifications described in this article, the enzymatic process requires a substantially lower concentration of methanol, because methanol inhibits lipase activity. A problem that has been encountered in this type of enzymatic conversion is the generation of water during the methyl esterification of the fatty acid. The water also was found to inhibit the enzyme activity. Various means to overcome this problem have been suggested, based on use of immobilized enzymes and multiple stages (Bélafi-bakó et al. 2002; Hsu et al. 2002; Shimada et al. 2002; Watanabe et al. 2002). 
While the enzymatic approach has been demonstrated as a route suitable for production of biodiesel, the reaction time required to achieve high rates of conversion has been considered to be a negative factor.

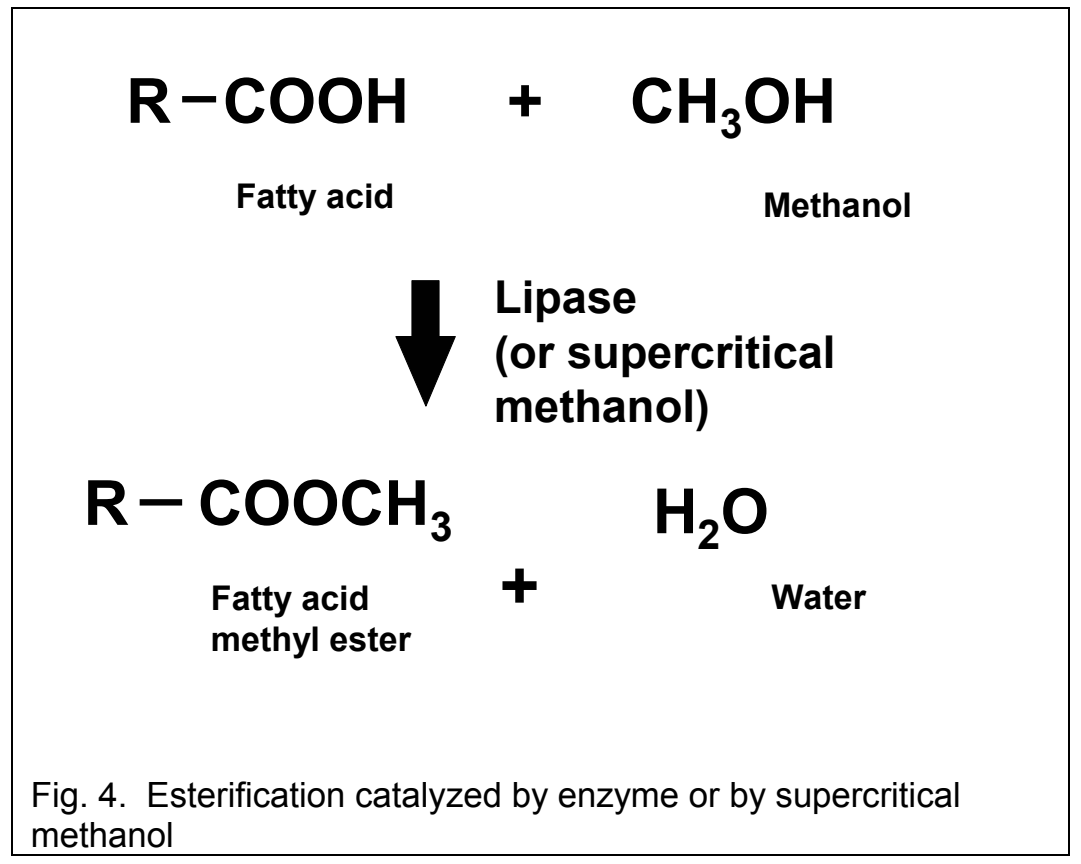

\section{Acid Catalysis}

Acid catalysis in methanol solution appears to be quite effective for converting free fatty acids (FFA) to esters, though the complete reaction, in samples that include triglycerides, may require 48 hours (Jeromin et al. 1987; Hammond 1998; Zhang et al. 2003a, Zheng et al. 2006). In order to apply such an approach to the case of low-grade vegetable oils, for instance, it would be necessary to employ a two-stage process in Figure 5. In the first stage the free fatty acids are converted to esters. In a second stage, alkalicatalyzed transesterification of the triglycerides present in the mixture is employed, as was illustrated in Fig. 1.

The latter reaction can be completed in much less time than would be possible with acid-catalyzed transesterification alone. Though acid catalysis of transesterification provides a way to avoid undesired saponification reactions, the reaction rates tend to be much lower, in comparison to the alkaline system. The ester conversion is strongly inhibited by the presence of water in the oil. If the water content is greater than $0.5 \%$, the ester conversion rate drops below 90\% efficiency (Canakci and van Gerpen 1999, 2001a; 2000b; 2000c). 


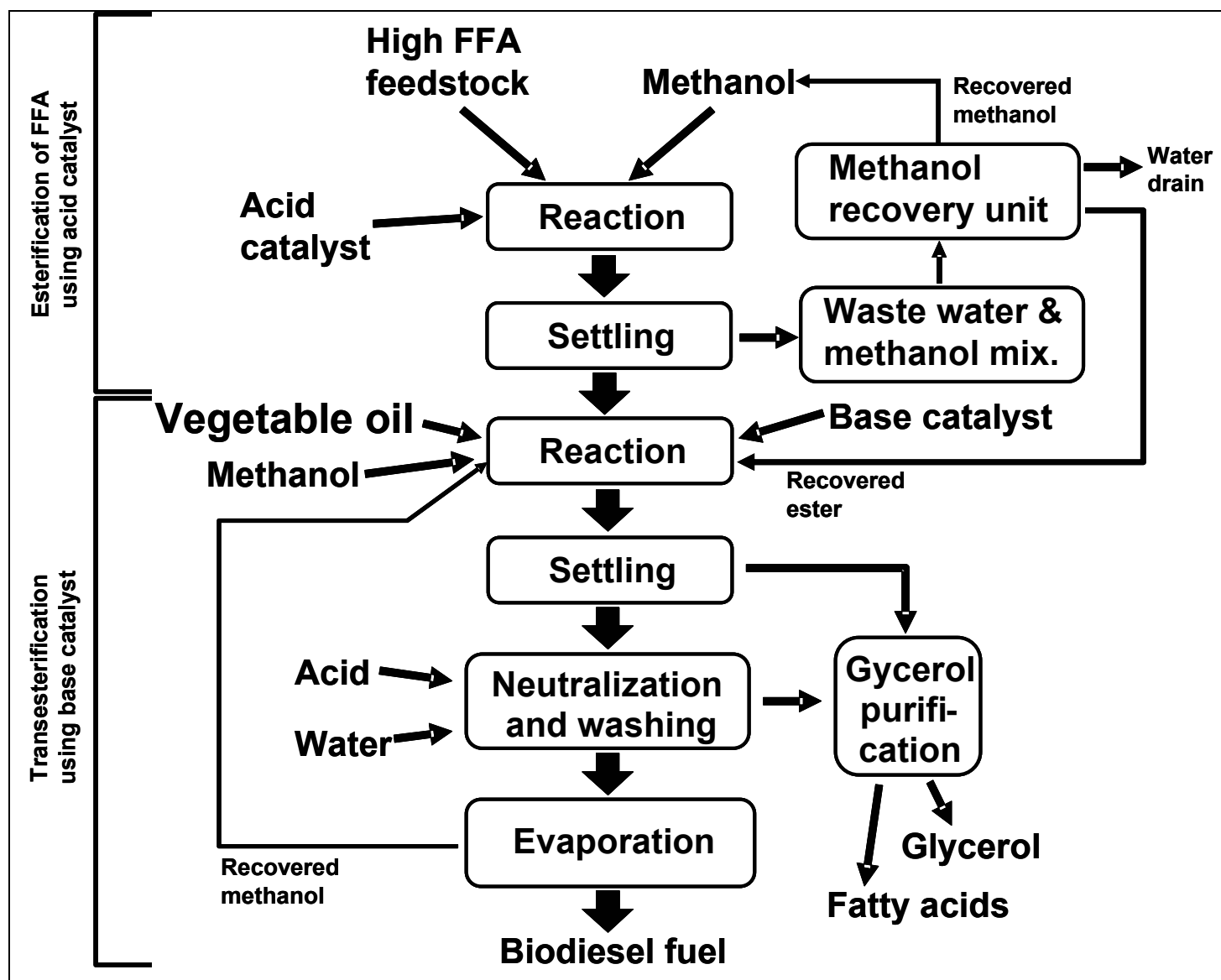

Fig. 5. Two-stage process; 1 . Esterification of high free fatty acids by acid catalyst and 2 . Transesterification of triglycerides by alkali catalyst

\section{Supercritical Methanol}

Two intriguing strategies for producing biodiesel from a wider range of mixtures, which may include fatty acids, water, and oils/fats, involve the use of supercritical conditions of methanol. The term "supercritical" means that the temperature and pressure of the solvent in question are sufficiently high, above its critical point, so that the properties of the solvent are neither completely liquid-like nor completely gas-like (Saka 2000; Arai et al. 2002; Brunner 2004). Supercritical conditions of methanol have been found useful for transesterification and esterification (Kusdiana and Saka 2001a, 2001b, 2004a, 2004b, 2004c; Saka and Kusdiana 2001a, 2001b; Warabi et al. 2004a, 2004b; Demirbas 2005; Imahara et al. 2006; Minami and Saka 2006). The first such method (Saka method) involves a one-step transesterification and esterification with supercritical methanol (Saka and Kusdiana 2001b; Kusdiana and Saka 2001a, 2001b). The second method (Saka-Dadan method) involves two steps; first, a hydrolysis with subcritical water, then, after separation of glycerol, a supercritical methylesterification of the fatty acids (Kusdiana and Saka 2004a; Minami and Saka 2006). Such non-catalytic performance by supercritical methanol is due to its increased ionic product, which assists the methanolysis reaction without 
catalyst. In addition, the decreased dielectric constant of methanol in the supercritical state results in better solubility of hydrophobic compounds in methanol such as triglycerides, diglycerides and monoglycerides, thus greatly promoting the reaction (Saka 2000; Kusdiana and Saka 2004a, 2004 c; Minami and Saka 2006).

Figure 6 illustrates the Saka-Dadan method. In the case of the initial hydrolysis reaction, a pressure of $10 \mathrm{MPa}$ and a temperature of $270{ }^{\circ} \mathrm{C}$ are sufficient to impart subcritical characteristics to water, making it possible to rapidly hydrolyze triglycerides to fatty acids. When the pressure is reduced, the mixture promptly separates into two phases, and the water phase can be separated to recover glycerol. Methanol becomes supercritical at a pressure of $10 \mathrm{MPa}$ and temperature of $270{ }^{\circ} \mathrm{C}$, and the supercritical conditions favor rapid formation of methyl esters from the fatty acids.

Compared to the methods involving alkali or acid catalysis, the supercritical method for biodiesel production has advantages in terms of reaction time and yield. Instead of 1-6 hours, the reaction is substantially complete in about 240 seconds (Kusdiana and Saka 2001a). A reaction time of at least 9 minutes can achieve a total glycerol content less than 0.24 mass percent, as required in biodiesel standards (ASTM D6751-03). Any free fatty acids become converted to methyl esters. No catalysts need to be recovered or neutralized at the end of the process. An additional advantage is that not only methanol but also some other alcohols such as ethanol, 1-propanol, 1-butanol, and even 1-octanol can be available for fatty acid alkyl esters production. The fact that no catalyst is used makes it relatively easy to obtain glycerol as a byproduct.

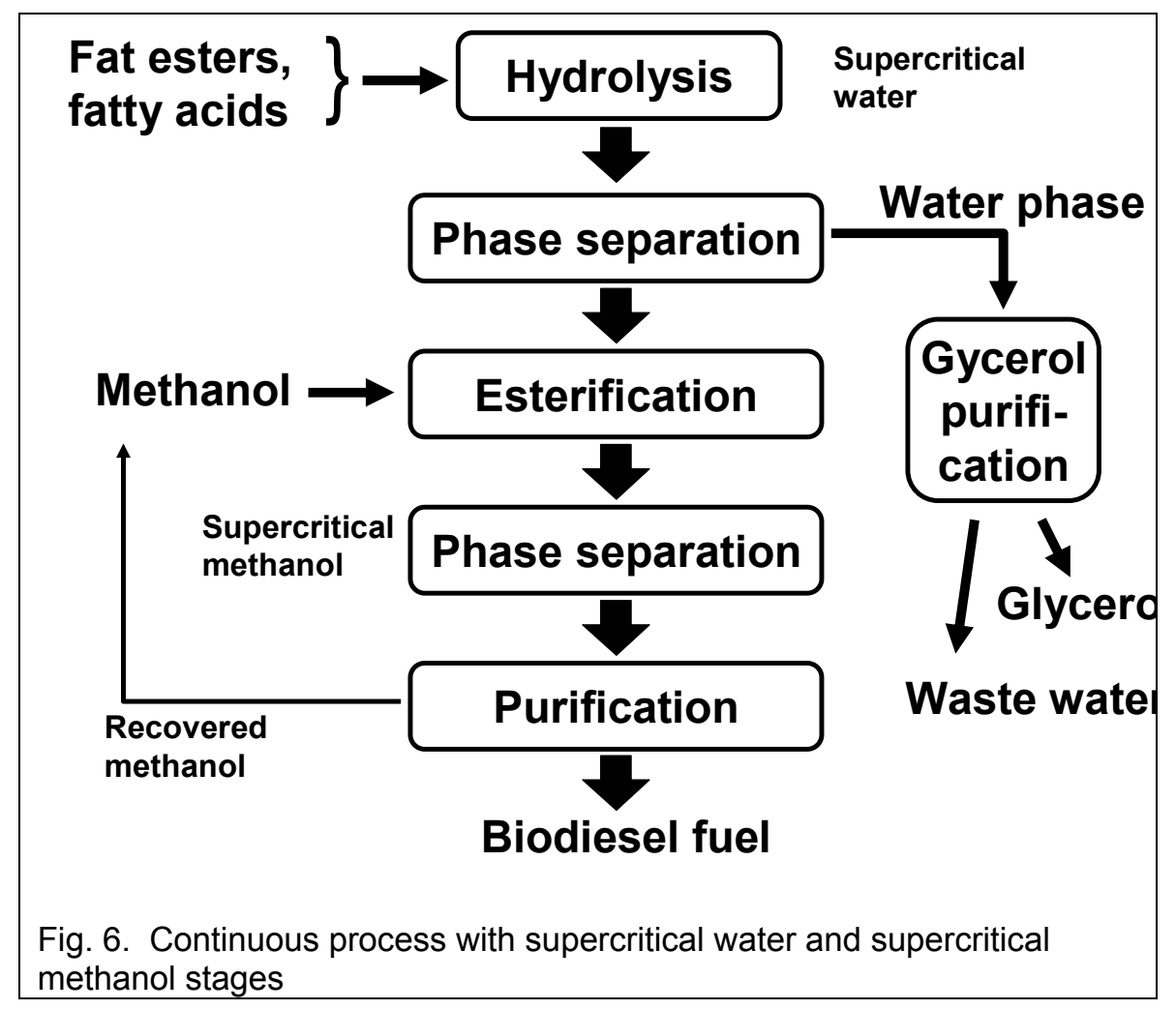


Though it is beyond the scope of the present article to provide a detailed economic assessment, practical considerations suggest that supercritical technology may become a favored production route for biodiesel in the years ahead. The relatively short times required for reaction imply that the process can be carried out in considerably lower volumes compared to the other methods described in this review. Large processing tanks, which are required by the other technologies considered in this review, can be avoided. Though high pressures are required, the amount of thermodynamic work is moderate, due to the limited compressibility of the fluids involved. Further savings, relative to some of the other technologies considered, involve avoidance of catalysts. The cost of catalysts, including alkali, acid, or solid-phase, can involve later separation or disposal. However, as in any new technology, engineering studies and scale-up work will be needed in order to obtain estimates of capital costs, processing costs, and expected lifetimes and efficiencies of equipment.

\section{PROSPECTS FOR TALL OIL AS A SOURCE MATERIAL FOR BIODIESEL}

Tall oil is a dark, viscous, and odorous liquid that phase-separates from the spent pulping liquor that remains after the kraft pulping of wood chips. The spent pulping liquor, commonly called black liquor, is a highly alkaline solution that contains the sodium soaps of rosin and fatty acids, byproducts of lignin, as well as inorganic ions, such as sulfate (Zachary 1965; Foran 1992). Crude tall oil forms a separate phase from the aqueous phase of black liquor following partial evaporation of the water. The majority of the soaps, together with other organic materials, can be removed at that point by skimming (Foran 1992). To promote separation, the mixture is acidified, converting the soaps into their respective free rosin acid and fatty acid forms (Zachary 1965). The aqueous phase is returned to the process, making it possible to reuse most of the sulfur and sodium for further pulping of wood. The composition of the extractives portion of typical tall oil is summarized in Table 1 (Holmlund and Parviainen 1999). As noted by Gullichsen and Lindeberg (1999), crude tall oil composition varies considerably, depending on the species of wood and the process conditions. Tall oil yields, per ton of kraft pulp, generally fall in a range between 18 and $60 \mathrm{~kg}$, with some higher numbers reported (Gullichsen and Lindeberg 1999).

Table 1. Composition of Tall Oil Extractives from Kraft Black Liquor

\begin{tabular}{|l|c|c|c|c|c|}
\hline Component & $\begin{array}{c}\text { N. Amer. } \\
\text { Softwood }\end{array}$ & $\begin{array}{c}\text { Scandinavian } \\
\text { Pine }\end{array}$ & $\begin{array}{c}\text { Scandinavian } \\
\text { Spruce }\end{array}$ & $\begin{array}{c}\text { N. Amer. } \\
\text { Hardwood }\end{array}$ & $\begin{array}{c}\text { N. Amer. } \\
\text { Birch }\end{array}$ \\
\hline Rosin acids (\%) & 42 & $30-35$ & $20-30$ & - & - \\
\hline Fatty acids (\%) & 47 & $50-55$ & $35-55$ & 76 & $55-90$ \\
\hline Neutrals (\%) & 11 & $5-10$ & $18-25$ & 24 & $5-35$ \\
\hline
\end{tabular}

As has been described in detail (Back and Allen 2000), some of the major components of crude tall oil are rosins, unsaponifiable sterols (5-10\%), resin acids (mainly 
abietic and its isomers), fatty acids (mainly palmitic, oleic, and linoleic acids), fatty alcohols, some sterols, and other alkyl hydrocarbon derivatives. Based on a total of $100 \%$, the organic content of typical tall oil is comprised of about 5-15\% volatiles ("tall oil heads" or "turpentine," e.g., pinene), 25-35\% fatty acids (or "soaps"), 5-15\% of "distilled tall oil" (including unsaponifiable compounds), 25-35\% rosins (as rosin soaps), and 15-25\% highermass compounds ("pitch") (Zinkel and Russell 1989). According to another source, fractionation of crude tall oil is said to result in about $35 \%$ rosin acids, $30 \%$ fatty acids, and $35 \%$ of distllates, head, and pitch by mass (see Coll et al. 2001). Figure 7 shows the chemical structures of several components that tend to be relatively abundant in crude tall oil samples (Wang et al. 2001, 2002; Zinkel and Russell 1989; Back and Allen 2000).

Raw soap from tall oil typically contains significant residual water (as black liquor), lignin, fiber, sodium, calcium, and inorganic acids (Holmlund and Parviainen 1999). Of these, the lignin (from the aqueous black liquor phase), the calcium, and the fibers are considered to be the main contaminants (Gullichsen and Lindeberg 1999). As a first step in processing, tall oil is dehydrated to remove water, heated, and then flashed into a chamber where the lower pressure permits vaporization of most of the components (Zachary et al. 1965). The separation of the organic materials from the aqueous phase is facilitated by acidification, converting soaps into their respective free rosin acid and free fatty acid forms.

A.

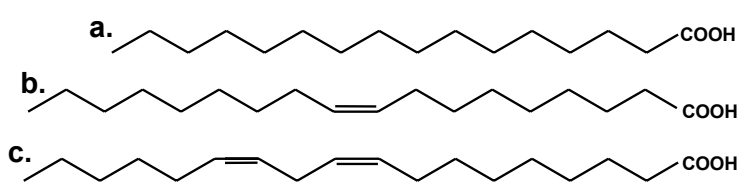

d.

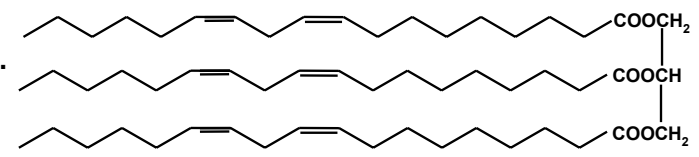

B.

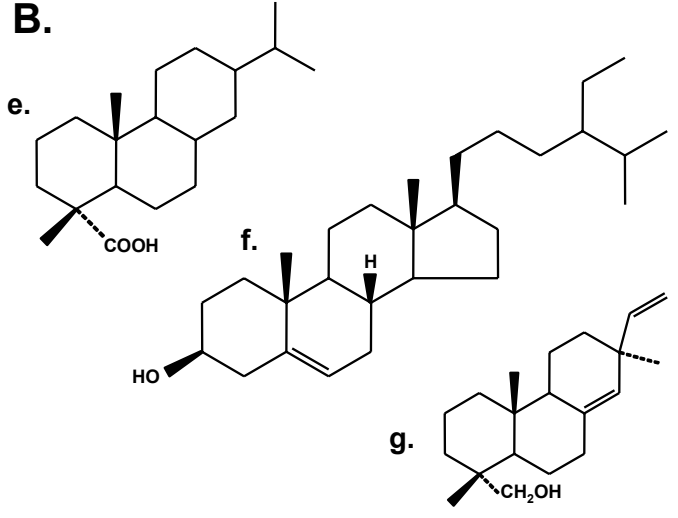

Fig. 7. Structures of some typical organic chemical species found in tall oil samples. Part A: Fatty acids and esters; a: palmitic acid; b: oleic acid; c: linoleic acid; d: triglyceride ester (fat) of linoleic acid. Part B: Resins and unsaponifiables; e: abietic acid (a rosin component); f: $\beta$-sitosterol (an unsaponifiable compound); g: pimarol (Wang et al. 2001, 2002; Zinkel and Russell 1989; Back and Allen 2000)

By distillation and other separation processes, crude tall oil can be separated it into a number of distinct fractions (Zinkel and Russell 1989). By further purification, reducing the rosin content to the range $1-10 \%$, one obtains tall oil fatty acid (TOFA). Fatty acids derived from tall oil differ from typical vegetable oils by being richer in oleic acid (a C18 acid with one double bond), somewhat less linolenic acid (C18 acid with two unsaturated bonds), and almost no linolenic acid (C18 acid with three unsaturated bonds) (Zachary et al. 1965). Following from a point made earlier in this review, such differences can be 
expected to reduce gum formation during combustion of tall oil biodiesel, in comparison to biodiesel obtain from vegetable oils (see Knothe 2005). Tall oil fatty acid is relatively inexpensive, and it can be used as an alternative to tallow fatty acids for production of soaps and lubricants. It also can be esterified with pentaerythritol and used in adhesives and oil-based varnishes. Tall oil also can be incinerated in a kraft liquor recovery boiler to recover its heat value, but the efficiency and relative safety of boiler operation tend to be reduced by such practices (Wong 1995).

Neutral fractions of tall oil typically are most prominent in the heads fraction of tall oil, the part of which distills first, before the rosin and fatty acid (Conner and Rowe 1975; Koebner 1983; Wang et al. 2001). Main species of the head fraction consist of resin alcohols (especially pimarol), steroids (especially $\beta$-sitosterol), fatty alcohols, diterpenes, sesquiterpenes, and resin aldehydes (Wang et al. 2001, 2002). Because neutral components of raw tall oil, as mentioned, can have other valuable uses, and due to their easy distillation, manufacturers would be expected to minimize the amounts carried over into streams intended for biodiesel production.

Table 2 summarizes some of the main hurdles, as well as some advantages of some of the conversion strategies already outlined in this article, with respect to their possible application in the case of tall oil as a source of biodiesel.

Table 2. Pros and Cons of Conversion Strategies for Biodiesel, Using Tall Oil from the Kraft Pulping of Wood

\begin{tabular}{|c|c|}
\hline Processing Strategies & Feasibility Issues \\
\hline Alkaline catalysis & Saponification can cause problems; coking of reactors \\
\hline Enzymatic catalysis & Slow; water removal required; multiple stages required \\
\hline Acid catalysis & Promising; requires follow-up by alkaline transesterification \\
\hline Supercritical methanol & Fast; high pressure equipment, development required \\
\hline Hydrogenation alone & Suitable for use as cetane enhancer in petrodiesel blends \\
\hline
\end{tabular}

As noted in Table 2, alkaline processing of tall oil fractions can be expected to suffer from saponification of the fatty acids, as well as from coking. Improved yields and reduced coke or pitch in the resulting biofuels have been achieved by use of methanol (Chantal et al. 1984), as well as different catalysts (Chantal et al. 1984; Baker and Elliot 1987), diluents (Sharma and Bakhshi 1991), or hydrogenation (Mathews et al. 1985; Baker and Elliot 1987) when producing the methyl esters of fatty acids obtained by wood. A relatively mild base, sodium carbonate, has been used in catalytic conversion of oils of poplar wood, obtained by high pressure liquefaction, using a zeolites catalyst (Sharma and Bakhshi 1991). The zeolite catalysts were found to be effective even in the absence of hydrogenation, but considerable coke formation was observed.

Progress has been achieved in studies of liquids obtained by pyrolysis or highpressure liquefaction of wood (Sharma and Bakhshi 1991). Though the high inorganic content renders pyrolysis impractical in the case of black liquor, the process appears well suited to the processing of tall oil components to make other chemical products.

Coll et al. (2001) noted that the rosin fraction of tall oil tends to be available in excess quantities, relative to market demand. In effect, some of the rosin is an excess 
byproduct of the separation and utilization of fatty acids and terpenoids from the pulping process. In order to convert such rosin into a useful biofuel, it is necessary to hydrogenate the double bonds within the ring structures of abietic acid and related isomers. Promising results were achieved by a catalytic hydrogenation and removal of carboxylic acids in a single-step hydrotreatment process.

Wong (1995) described catalytic hydrogenation of tall oil, yielding a product that can be used as an additive in petrodiesel fuel. It was not necessary to separate fatty acids from rosin components of the de-pitched tall oil mixture. Furthermore, no esterification was carried out.

Only limited work has been carried out using supercritical conditions to treat tall oil products. Taylor and King (2001) used supercritical carbon dioxide, containing a lesser amount of methanol, as a medium within which to evaluate the efficacy of various enzymes as catalysts for esterification. Though fatty acid methyl esters were produced, the aim of these researchers was tall oil analysis, rather than biodiesel production. The conversion rates were low, and the authors concluded that the supercritical conditions adversely affected the tertiary structure of the enzymes, relative to their intended activity. Other authors have employed supercritical $\mathrm{CO}_{2}$ as a means of extracting oleophilic substances from wood (Harvala et al. 1987) or from tall oil itself (Ritter and Campbell 1991).

The foregoing results, while hardly demonstrating viable supercritical production of biodiesel from tall oil, at least provide some precedent for further research in that direction. The tolerance of supercritical conditions for relatively high levels of free carboxylic acids and water would appear to offer special advantages in the case of tall oil.

\section{Economic and Practical Motivations for Tall Oil Use}

Though the discussion in the preceding paragraphs suggests various potentially feasible approaches to biodiesel production from tall oil fractions, it is not a forgone conclusion that the pulp and paper industry will rush to embrace any of these technologies. In qualitative terms, a venture into bio-fuels can be perceived as a risk, at least until another company has demonstrated the technological success. Even then, a large pulp and paper company may be reluctant to become involved in a technology that they do not think of as being part of their core business.

A key factor that has potential to help make tall-oil-to-diesel technology a reality is the price differential. The heat value of tall oil, as it is used to produce steam, is about 35$40 \mathrm{MJ} / \mathrm{kg}$ of solids (Wong 1995). The historical price of tall oil has been in the range of $\$ 90$ to $\$ 160$ per ton of solids from 1997 to 2002 (Innov. Group 2006). The price has risen recently by $50 \%$ (Anon. 2006) and the market is expected to tighten further as a general trend (Guzman 2002). If one uses $\$ 200$ as a round-number estimate for the price per short ton of crude tall oil, the corresponding price per gallon is about $\$ 0.80$. The wholesale price of diesel fuel is considerably higher. During the period between January 2004 and the present, the price of petrodiesel approximately doubled, reaching about $\$ 2.90$ per gallon (DOE 2006a). In addition to the present price levels, investors also will be interested in longer-term forecasts of fuel prices. Engineering studies are needed to determine at what point the price difference is enough to trigger investments in the equipment changes needed to deal with specific issues related to the processing of tall oil as a biodiesel source. 
Recent work by Uloth (2006) has helped to document an additional incentive for kraft pulp producers to convert tall oil for higher-value products, rather than just crude tall oil or direct combustion. More effective removal of tall oil soaps from black liquor was found to increase the capacity of recovery boilers by $2-8 \%$. Because the kraft recovery boiler is often a process bottleneck, such changes can significantly increase the overall production capacity of a pulp mill. Advances in soap-skimming technology (Uloth and Wearing 1994; Propst 1995; Piirtinen et al. 2004) also can contribute to the feasibility of future tall-oil-to-biodiesel ventures.

\section{Summary}

A variety of technological approaches may be used, including alkali- and acidcatalyzed esterification, transesterification, reactions in supercritical fluids, enzymatic conversions, and hydrogenation. Options involving supercritical methanol appear to be especially promising. Given the economic incentives, it appears probable that the kraft pulping process can become a significant source of biodiesel oil, helping to replace increasingly expensive petrodiesel products. Further research is needed in all of these fields as we continue to seek the most cost-effective, environmentally responsible, and energetically efficient schemes to power motor vehicles in the future.

\section{ACKNOWLEDGEMENTS}

The present article grew out of activities related to the Ph.D. thesis candidacy of Sa Yong Lee. Support for the thesis was obtained from the National Research Initiative of the USDA Cooperative State Research, Education and Extension Service, grant number 200435504-14655.

\section{REFERENCES CITED}

Abigor, R. D., Uadia, P. O., Foglia, T. A., Haas, M. J., Jones, K. C., Okpefa, E., Obibuzor, J. U., and Bafor, M. E. (2000). "Lipase-catalysed production of biodiesel fuel from some Nigerian lauric oils," Biochem. Soc. 28, 979-981.

Anon. (2006). "Raw materials hot spots," Raw Materials Facts 3(1), 2, http://www.nationalstarch.com/pdf/06-0062_RMF_3-06_Final.pdf.

Arai, Y., Sako, T., and Takebayashi, Y. (2002). Supercritical Fluids: Molecular Interactions, Physical Properties, and New Applications, Springer, New York.

Arsan, J., and Parkin, K. L. (2000). "Selectivity of Candida antarctica B lipase toward fatty acid and (iso)propanol substrates in esterification reactions in organic media," $J$. Agricultural Food Chem. 48, 3738-3743.

Axegard, P., Backlund, B., and Warnqvist, B. (2002). "The eco-cyclic pulp mill. Focus on closure, energy-efficiency and chemical recovery development," Pulp Paper Can. 103(5), 26-29. 
Back, E. L., and Allen, L. H., Eds. (2000). Pitch Control, Wood Resin and Deresination, TAPPI Press, Atlanta, GA.

Bagby, M. O., Freedman, B., and Schwab, A. W. (1987). "Preparation and properties of diesel fuels from vegetable-oils," Fuel 66(10), 1372-1378.

Baker, E. G., and Elliot, D. C. (1987). "Catalytic hydrotreating of biomass-derived oils," ACD, Div. Fuel Chem. 32(2), 257-263.

Bélafi-bakó, K., Kovács, F., Gubicza, L., and Hancsók, J. (2002). "Enzymatic biodiesel production from sunflower oil by Candida antarctica lipase in a solvent-free system," Biocatalysis Biotrans. 20(6): 437-439.

Berndes, B., Hoogwijk, M., and van den Broek, B. (2003). "The contribution of biomass in the future global energy supply: A review of 17 studies," Biomass Bioenergy 25(1), $1-28$.

Bournay, L., Casanave, D., Delfort, B., Hillion, G., and Chodorge, J. A. (2005). "New heterogeneous process for biodiesel production: A way to improve the quality and the value of the crude glycerin produced by biodiesel plants," Catalysis Today 106, 190192.

Brunner, G., ed. (2004). Supercritical Fluids as Solvents and Reaction Media, Elsevier, Boston.

Canakci, M., and Van Gerpen, J. (1999). "Biodiesel production via acid catalysis," Trans. ASAE 42(5), 1203-1210.

Canakci, M., and Van Gerpen, J. (2001a). "Biodiesel production from oils and fats with high free fatty acids," Transaction of the ASAE 44(6): 1429-1436.

Canakci, M., and Van Gerpen, J. (2001b). "Accelerated oxidation process in biodiesel," Trans. ASAE 42(6), 1565-1572.

Canakci, M., and Van Gerpen, J. (2001c). "A pilot plant to produce biodiesel from high free fatty acid feedstocks,” 2001 ASAE Annual International Meeting Paper No. 016049, Sacramento, California.

Chantal, P., Kaliaguine, S., Grandmaison, J. L., and Mahay, A. (1984). "Production of hydrocarbons from aspen poplar pyrolytic oils over HZSM-5," Applied Catalysis 10(3), 317-332.

Clark, S. J., Wagner, L., Schrock, M. D., and Piennaar, P. G. (1984). "Methyl and ethyl soybean esters as renewable fuels for diesel-engines," J. Amer. Oil Chemists Soc. 61(10), 1632-1638.

Coll, R., Udas, S., and Jacoby, W. A. (2001). "Conversion of the rosin acid fraction of crude tall oil into fuels and chemicals," Energy Fuels 15, 1166-1172.

Conner, A. H., and Rowe, J. W. (1975). "Neutrals in southern pine tall oil," J. Amer. Oil Chemists Soc. 52(9), 334-338.

Cook, C., Mies, W., Min, T., Rudder, G., and Smith, B. (2005). "Final, some good news," Pulp Paper Intl. 47(1), 26-28.

da Rosa, A. V. (2005). Fundamentals of Renewable Energy Processes, Elsevier, New York.

DeKing, N. (2004). Pulp \& Paper Global Fact \& Price Book 2003-2004, Paperloop, San Francisco, CA. 
Demirbas, A. (2005). "Biodiesel production from vegetable oils via catalytic and noncatalytic supercritical methanol transesterification methods," Prog. Energy Combustion Sci. 31(5-6), 466-487.

Dittmar, T., Dimmig, T., Ondruschka, B., Heyn, B., Haupt, J., and Lauterbach, M. (2003). "Production of fatty acid methyl esters from rapeseed oil and spent fat in batch operation," Chemie Ingenieur Technik 75(5), 595-601.

DOE (2006a). "Weekly Retail On-Highway Diesel Prices," http://tonto.eia.doe.gov/oog/info/wohdp/diesel.asp.

DOE (2006b). "Biodiesel Handing and Use Guidelines," $D O E / G O 102006-2288,2^{\text {nd }}$ Ed., March 2006, U.S. Dept. of Energy.

Drake, F. (2000). Global Warming: The Science of Climate Change, Arnold, London.

Dunn, R. O. (1999). "Thermal Analysis of Alternative Diesel Fuels from Vegetable Oils," J. Amer. Oil Chemists Soc. 76(1), 109-115.

Encinar, J. M., González, J. F., and Rodríquez-Reinares, A. (2005). "Biodiesel from used frying oil. Variables affecting the yields and characteristics of the biodiesel," Industrial \& Engineering Chemistry Research 44(15), 5491-5499.

Felizardo, P., Neiva Correia, M. J., Raposo, I., Mendes, J. F., Beremeier, R., and Moura Bordado, J. (2006). "Production of biodiesel from waste frying oils," Waste Management 26(5), 4870494.

Foran, C. D. (1992). "Tall oil soap recovery," in Chemical Recovery in the Alkaline Pulping Processes, $3^{\text {rd }}$ Ed., R. P. Green and G. Hough, eds., TAPPI Press, Atlanta, Ch. 4, 45-56.

Goering, C. E., Schwab, A. W., Dangherty, M .J., Pryde, E. H., and Heakin, A. J. (1982). "Fuel properties of eleven vegetable oils," Transaction of the ASAE 25(6), 1472-1477.

Groschen, R. (2002). "Overview of the feasibility of biodiesel from waste/recycled greases and animal fats," Legislative Commission on Minnesota Resources "Evaluate Biodiesel from Waste Fats and Oils, ” Marketing Services Division, Minnesota Department of Agriculture.

Gryglewicz, S. (1999). "Rapeseed oil methyl esters preparation using heterogeneous catalysts," Bioresour. Technol. 70 (3), 249-253.

Gullichsen, J., and Lindeberg, H. (1999). "Byproducts of chemical pulping," in Chemical Pulping, J. Gullichsen and C.-J. Fogelholm, eds., Fapet Oy, Papermaking Sci. Technol. Ser. 6B, Ch. 18, B375-B389.

Guzman, D. de. (2002). "TOFA outlook improves on tightening vegetable oils and CTO consolidation," Chem. Market Reporter, Feb.

Hammond, E. G. (1998). Personal communication, Dept. of Food Science, Iowa Sate Univ., Ames, Iowa.

Harvala, T., Alkio, M., and Komppa, V. (1987). "Extraction of tall oil with supercritical carbon-dioxide," Chem. Eng. Res. Design 65(5), 386-389.

Hirsch, R. L., Bezdek, R., and Wendling, R. (2006). "Peaking of world oil production and its mitigation," AIChE J. 52(1), 2-8.

Holmlund, K., and Parviainen, K. (1999). "Evaporation of black liquor," in Chemical Pulping, J. Gullichsen and C.-J. Fogelholm, eds., Fapet Oy, Papermaking Sci. Technol. Ser. 6B, Ch. 12, B37-B93. 
Hsu, A-F. Jones, K., Foglia, T. A., and Marmer, W. N. (2002). "Immobilized lipasecatalysed production of alkyl esters of restaurant grease as biodiesel," Biotech. Appl. Biochem. 36(3), 181-186.

Hunt, V. D. (1983). Synfuels Handbook, International Press, New York.

Hunter, J. E., and Applewhite, T. H. (1993). "Correction of dietary-fat availability estimates for wastage of food-service deep-frying fats," J. Amer. Oil Chemists Soc. 70(6), 613617.

Imahara, H., Minami, E., and Saka, S. (2006). "Thermodynamic study on cloud point of biodiesel with its fatty acid composition," Fuel 85, 1666-1670.

Innov. Group. (2006).

Jeromin, L., Peukert, E., and Wollmann, G. (1987) "Process for the pre-esterification of free fatty acids in fats and oils, U.S. Patent No. 4698186.

Johansson, A. (1982). "By-product recovery and valorization in the kraft industry - A review of current trends in the recovery and use of turpentine and tall oil derivatives," Biomass 2(2), 103-113.

Johnson, L. A., and Hammond, E. G. (1996). "Soybean oil ester fuel blends," U.S. Patent 5,520,708.

Kavalov, B., and Peteves, S. D. (2005). Status and perspectives of biomass-to-liquid fuels in the European Union, European Union Directorate General, Joint Research Center, Inst. for Energy, The Netherlands, AUR 21745 EN.

Knothe, G. (2005). "Dependence of biodiesel fuel properties on the structure of fatty acid alkyl esters," Fuel Proc. Technol. 86(10), 1059-1070.

Koebner, A. (1983). "Separation of tall oil head fraction into fatty acids and unsaponifiables," J. Wood Chem. Technol. 3(4), 413-420.

Kreutzer, U. R. (1984). "Manufacture of fatty alcohols based on natural fats and oils," $J$. Amer. Oil Chemists Soc. 61(2), 343-348.

Kulkarni, M. G., and Dalai, A. K. (2006). "Waste cooking oil - An economical source for biodiesel: A review," Ind. Eng. Chem. Res. 45(9), 2901-2913.

Kusdiana, D., and Saka, S. (2001a). "Methyl esterification of free fatty acids of rapeseed oil as treated in supercritical methanol," J. Chem. Eng. Japan 34(3), 383-387.

Kusidana, D., and Saka, S. (2001b). "Kinetics of transesterification in rapeseed oil to biodiesel fuel as treated in supercritical methanol," Fuel 80, 693-698.

Kusdiana, D., and Saka, S. (2004a). "Two-step preparation for catalyst-free biodiesel fuel production," Appl. Biochem. Biotechnol. 115, 781-791.

Kusdiana, D., and Saka, S. (2004b). "Catalytic effect of metal reactor in transesterification of vegetable," JAOCS 81, 103-104.

Kusdiana, D., and Saka, S. (2004c). "Effects of water on biodiesel fuel production by supercritical methanol treatment," Bioresource Technol. 91, 289-295.

Labohm, H., Rozendaal, S., and Thoenes, D. (2004). Man-Made Global Warming: Unravelling a Dogma, Multi-Science Publ., Brentwood, Essex, UK.

Lang, X., Dalai, A. K., Bakhshi, N. N., Reaney, M. J., and Herts, P. B. (2001). "Preparation and characterization of bio-diesels from various bio-oils, Bioresource Technol. 80(1), 53-62. 
Lee, S. (1996). Alternative Fuels, Applied Energy Technol. Ser., Taylor and Francis, Washington, DC.

Lomborg, B. (2001). The Skeptical Environmentalist. Measuring the Real State of the World, Cambridge Univ. Press, Cambridge, UK.

Ma, F., Clements, L. D., and Hanna, M. A. (1998) "The effect of catalyst, free fatty acids, and water on transesterification of beef tallow," Trans. ASAE, 41, 1261-1264.

Mathews, J. F., Teplo, M. G., Eager, R. L., and Pepper, J. M. (1985). "Upgrading of poplar wood oil over HZSM-5 zeolite catalysis," Can. J. Chem. Eng. 63(4), 686-689.

McKay, H. (2006). "Environmental, economic, social, and political drivers for increasing use of woodfuel as a renewable resource in Britain," Biomass Bioenergy 30(4), 308315.

Minami, E., and Saka, S. (2006). "Kinetics of hydrolysis and methyl esterification for biodiesel production in two-step supercritical methanol process," Fuel, in print.

Mittelbach, M. (1996). "Diesel fuel derived from vegetable oils. VI. Specification and quality control of biodiesel," Bioresource Technology 56(1), 7-11.

Noureddini, H. (2000). "Process for producing biodiesel with reduced viscosity and a cloud point below thirty-two (32) degrees fahrenheit," U.S. Pat. 6,015,440.

Noureddini, H. (2001). "System and process for producing biodiesel fuel with reduced viscosity and a cloud point below thirty-two (32) degrees fahrenheit," U.S. Pat. $6,174,510$.

OECD/IEA. (2000). Energy Technology and Climate Change: A Call to Action, International Energy Agency, Organization for Economic Co-operation and Development, Paris.

Pestes, M. N. and Stanislao, J. (1984). "Piston ring deposits when using vegetable oil as a fuel," J. Testing Eval. 12(2), 61-68.

Peterson, C. L., Reece, D. L., Thompson, J. C., Beck, S. M., and Chase, C. (1996). "Ethyl ester of rapeseed used as a biodiesel fuel. A case study," Biomass \& Bioenergy 10(5-6), 331-336.

Piirtinen, E., Stenius, P. Vuorinen, T., Kovasin, K., and Ala-Kaila, K. (2004). "A new method to improve soap separation in black liquor by adding extracted neutrals of tall oil," 2004 TAPPI Fall Tech. Conf.: Engineering and Pulping Proc., TAPPI Press, Atlanta, 505-515.

Propst, M. (1995). "Pine notes: Skimming off the top," Naval Stores Rev. 105(6), 14.

Ritter, D. C., and Campbell, A. G. (1991). "Supercritical carbon-dioxide extraction of southern pine and ponderosa pine," Wood Fiber Sci. 23(1), 98-113.

Saka, S. (2000). "Chemical conversion of wood by supercritical water, "ASAST 35, 5-10.

Saka, S., and Kusdiana, D. (2001). "Biodiesel fuel from rapeseed oil as prepared in supercritical methanol," Fuel 80, 225-231.

Schuchardt, U., Sercheli, R., and Vargas, R. M. (1998). "Transesterification of vegetable oils: A review," J. Braz. Chem. Soc. 9(1), 199-210.

Sharma, R. K., and Bakhshi, N. N., "Upgrading of wood-derived bio-oil over HZSM-5," Bioresource Technol. 35, 57-66. 
Sheehan, J., Camobreco, V., Duffield, J., Graboski, M, and Shapouri, H. (1998). An Overview of Biodiesel and Petroleum Diesel Life Cycles, National Renewable Energy Laboratory (NREL), Golden, CO, TP-580-24772.

Shimada, Y., Watanabe, Y., Sugihara, A., and Tominaga, Y. (2002). "Enzymatic alcoholysis for biodiesel fuel production and application of the reaction to oil processing," Journal of Molecular Catalysis B: Enzymatic 17, 133-142.

Shimada, Y., Watanabe, Y., Sugihara, A., Baba, T., Ooguri, T., Moriyama, S., Terai, T., and Tominaga, Y. (2001). "Ethyl esterification of docosahexaenoic acid in an organic solvent-free system with immobilized Candida antarctica lipase," J. Biosci. Bioeng. 92(1), 19-23.

Smook, G. A. (1992). Handbook for Pulp and Paper Technologists. $2^{\text {nd }}$ Ed., Angus Wilde Publ., Vancouver.

Song, C., Hsu, C. S., and Mochida, I. (2000). Chemistry of Diesel Fuels. Applied Energy Technol. Ser., Taylor and Francis, London.

Suppes, G. J., Basari, M. A., Doskocil, E. J., Mankidy, P. J., and Goff, M. J. (2003). "Transesterification of soybean oil with zeolite and metal catalysts," Appl. Catal., A 257, 213-223.

Supple, B., Howard-Hildige, R., González-Gómez, E., and Leahy, J. J. (2002). “The effect of steam treating waste cooking oil on the yield of methyl ester," J. Amer. Oil Chemists Soc. 79(2), 175-178.

Taylor, S. L., and King, J. W. (2001). "Fatty and resin acid analysis in tall oil products via supercritical fluid extraction - supercritical fluid reaction using enzymatic catalysis," $J$. Chromatographic Sci. 39(7), 269-272.

Tester, J. W., Drake, E. M., Driscoll, M. J., Golay, M. W., and Peters, W. A. (2005). Sustainable Energy: Choosing Among Options. MIT Press, Cambridge, MA.

Tomasevic A. V., and Siler_Marinkovic S. S. (2003). "Methanolysis of used frying oil," Fuel Processing Technol. 81(1), 1-6.

Tyson, K. S., and McCormick, R. L. (2006) "Biodiesel Handling and Use Guidelines Second Edition," Energy Efficiency and Renewable Energy, U.S. Department of Energy, Technical Report, DOE/GO-102006-2288.

Uloth, V. C. (2006), "Tall oil and tall oil soap recovery," http://wcm.paprican.ca/wcmpaprican/publishing.nsf/AttachmentsByTitle/BO_Tall_Oil_ Soap_PDF_Eng/\$FILE/0225-E-TallOilSoapRecovery.pdf.

Uloth, V. C., and Wearing, J. T. (1994). "Use of lignosulfonate solutions to increase both soap recovery and tall-oil production efficiency," Naval Stores Rev. 104(3), 8-12.

Van Gerpen, J., Shanks, B., Pruszko, R., Clements, D., and Knothe, G. (2004a). "Biodiesel analytical methods," NREL/SR-510-36240, National Renewable Energy Laboratory, Colorado, USA.

Van Gerpen, J., Shanks, B., Pruszko, R., Clements, D., and Knothe, G. (2004b). "Biodiesel production technology," NREL/SR-510-36244, National Renewable Energy Laboratory, Colorado, USA.

Vasudevan, P., Sharma, S., and Kumar, A. (2005). "Liquid fuel from biomass: An overview," J. Sci. Indust. Res. 64(11), 822-831. 
Vellguth, G. (1988). "Vegetable oil as diesel fuel substitute," Landbauforschung Völkenrode 38(1), 12-16.

Wang, S.-F., Furuno, T., and Cheng, Z. (2002). "Study of the extraction of phytosterol from mason pine raw tall oil," J. Wood Sci. 48(6), 505-511.

Wang, S.-F., Furuno, T., Cheng, Z., and Katoh, S. (2001). "Composition of neutral fraction in Chinese raw tall oil," J. Wood Sci. 47(5), 400-405.

Wang, P. S., Tat, M. E., and van Gerpen, J. (2005). "The production of fatty acid isopropyl esters and their use as a diesel engine fuel," JAOCS 82(11), 845-849.

Warabi, Y., Kusdiana D., and Saka, S. (2004a). "Reactivity of triglycerides and fatty acids of rapeseed oil in supercritical alcohols," Bioresource Technol. 91, 283-287.

Warabi, Y., Kusdiana D., and Saka, S. (2004b). "Biodiesel fuel from vegetable oil by various supercritical alcohols," Appl. Biochem. Biotechnol. Executive Editor: Ashok Mulchandani, Humana Press, vol. 115, 793-791.

Watanabe, Y., Pinsirodom, P., Nagao, T., Kobayashi, T., Nishida, Y., Takagi, Y., and Shimada, Y. (2005). "Production of FAME from acid oil model using immobilized Candida antarctica lipase," J. Amer. Oil Chemists Soc. 82(11), 825-831.

Watanabe, Y., Shimada, Y., Sugihara, A., and Tominaga, Y. (2002). "Conversion of degummed soybean oil to biodiesel fuel with immobilized Candida antarctica lipase," J. Molecular Catalysis B: Enzymatic 17, 151-155.

Wong, A. (1995). "Tall oil-based cetane enhancer for diesel fuel," Pulp Paper Can. 96(11), 37-40.

Wyman, C. E., and Goodman, B. J. (1993). "Biotechnology for production of fuels, chemicals, and materials from biomass," Appl. Biochem. Biotechnol. 39/40, 41-59.

Yuan, W., Hansen, A. C., Zhang, Q, and Tan, Z. (2005). "Temperature-dependent kinematic viscosity of selected biodiesel fuels and blends with diesel fuel," J. Amer. Oil Chem. Soc. 82(3), 195-199.

Zachary, L. G., Bajak, H. W., and Eveline, F. J. (1965). Tall Oil and its Uses, Dodge Co., Div. McGraw-Hill, New York.

Zaher, F. A., Megahed, O. A., and El Kenawy, O. S. (2003). "Utilization of used frying oil as diesel engine fuel," Energy Sources 25(8), 818-826.

Zhang, Y., Dubé, M. A., McLean, D. D., and Kates, M. (2003a). "Biodiesel production from waste cooking oil: 1. Process design and technological assessment," Bioresource Technol. 89(1), 1-16.

Zhang, Y., Dubé, M. A., McLean, D. D., and Kates, M. (2003b). "Biodiesel Production from Waste Cooking Oil: 2. Process Design and Technological Assessment," Bioresource Technology 90 (3), 229-240.

Zheng, S., Kates, M., Dubé, M. A., and McLean, D. D. (2006). “Acid-catalyzed production of biodiesel from waste frying oil," Biomass Bioenergy 30(3), 267-272.

Zinkel, D. F., and Russell, J., eds. (1989). Naval Stores, Production, Chemistry and Utilization, Pulp Chemicals Assoc.

Article submitted: June 16, 2006; Revision accepted: Aug. 3, 2006; Published Aug. 4, 2006 